\title{
Geomechanical modeling - workflow and Applications
}

- Pham Son Tung

- Mai Cao Lan

Faculty of Geology \& Petroleum Engineering, Department of Drilling \& Production, Ho Chi Minh city University of Technology, VNU-HCMC

(Manuscript Received on July 05 ${ }^{\text {th }}$, 2015; Manuscript Revised on September 30 ${ }^{\text {th }}$, 2015)

\begin{abstract}
This work aimed to present a detailed workflow for building a geomechanical model. For a case study, the workflow is then applied to a horizontal well X. The first step in building a geomechanical model is gathering data regarding well information (tubing, casing, deviation...), geological information (type of fault, permeability, reservoir radius, skin...), logs data (density, resistivity, sonic, caliper...), in-situ test data (leak-off test, formation test,...) and core data (tensile strength test, fracture toughness test, tri-axial test...). The second step is to build the geomechanical model using data analysis so that information about state of stress (vertical and principal horizontal stresses, pore pressure, concentration stress around wellbore) and rock mechanical properties (unconfined compressive strength, tensile strength, fracture toughness, Young modulus, Poisson ratio) can

be determined. Moreover, the differences in data analysis for vertical and horizontal wells were also mentioned in this work. Furthermore, it is evident that the more data we get, the more accurately a geomechanical model can be built. However, in reality, not all necessary data can be obtained, so this work also explained how to draw the most information from available data so that we can minimize the number of assumptions and uncertainties. An accurate geomechanical model is very essential for others works such as well bore stability or performance prediction of a well stimulation technique. The case study of this work presented the geomechanical modeling for the well $X$. The paper then presented the application of geomechanical modeling for the Evaluation of High Energy Gas Fracturing performance as well as for Sand Control analysis.
\end{abstract}

Key words: Geomechanic Modeling, High Energy Gas Fracturing, Sand Control.

\section{INTRODUCTION}

Geomechanics in petroleum industry deals with issues in geosciences related to rock mechanics. Geomechanics is used to predict important parameters such as in-situ stresses (vertical and principal horizontal stresses, pore pressure, concentration stress around wellbore) and rock mechanical properties (unconfined compressive strength, tensile strength, fracture toughness, Young modulus, Poisson ratio). In case of necessary, geological information (type 
of fault, permeability, reservoir radius, skin...) can also be included in geomechanics study.

Geomechanical evaluation is useful for the study of wellbore stability as well as for predicting the performance of reservoir stimulation works (for example, hydraulic fracturing/high energy gas fracturing). As these works demand considerably high in financial support and in time, having an accurate geomechanical model is therefore essentially important in petroleum industry.

Building a geomechanical model requires different scales data collection: from large scale, such as world stress map project [1], [2], reservoir/regional scale (stress map, type of fault...), to well scale, such as logs data (density, resistivity, sonic, caliper...), and to core scale, such as core test (tensile strength test, fracture toughness test, tri-axial test...). Multiple scales data collection is necessary because stress magnitudes and orientation are frequently not homogeneous on a reservoir scale, and can be substantially modified by presence of faults as well as lithological changes and contrast in rock mechanical properties [3], [4]. In some faultcontrolled reservoirs, local stress reorientations of up to $90^{\circ}$ relative to the regional trend have been reported [5], [6]. In such cases, inference of local in situ stress orientations from regional scale maps would inevitably lead to an incorrect pre-drilling prediction. Regarding local stresses, they vary in function of depth and type of rocks, as well as type of fault and type of pore pressure (normal or abnormal), so core test data is also needed to calibrate the geomechanical model.

In this paper, we present a detailed workflow to build and calibrate geomechanical models. We also discuss some essential differences in geomechanical models of horizontal and vertical wells. As we explained in the previous paragraph, the accurate level of a geomechanical model depends on the available data. In reality, not all necessary data can be obtained, so we also explain in this paper how to draw the most information from available data so that we can minimize the number of assumptions and uncertainties. Subsequently, the workflow is applied to a horizontal well X. Then, the gemechanical model freshly built is used to predict the well stimulation's performance using High Energy Gas Fracturing. Another application is to study the Sand Control.

\section{GENERAL WORKFLOW IN BUILDING A GEOMECHANICAL MODEL}

The general workflow in building a geomechanical model consists of two main steps: 1) Data acquisitions \& Analysis; 2) Geomechanical modelling. This workflow can be viewed in Figure 1.

In data acquisition step, we must collect as many data as possible because the more data is available, the less uncertainties and assumptions we have to make, hence the more accurate the geomechanical model is. However, in reality not all necessary data can be obtained, so we must know how to draw the most information from available data. Therefore, we present in Table 1 different possible ways to determine in-situ stresses and rock mechanical properties, so that the user can decide which way to follow depending on the available data.

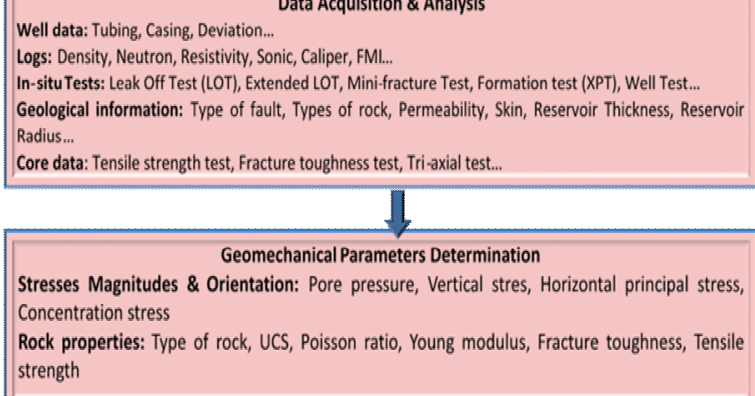

Geomechanical Parameters Determination Stresses Magnitudes \& Orientation: Pore pressure, Vertical stres, Horizontal principal stress, Concentration stress

Rock properties: Type of rock, UCS, Poisson ratio, Young modulus, Fracture toughness, Tensile strength

Figure 1. General workflow in geomechanical modelling [7] 
Table 1. Building a geomechanical model using different kinds of data.

\begin{tabular}{|c|c|c|c|c|}
\hline & \multirow{2}{*}{ Data Abilitv Decreases } & \\
\hline & & & & \\
\hline & $\begin{array}{c}\text { Geomechanical } \\
\text { Properties }\end{array}$ & $\begin{array}{c}\text { Data used for model } \\
\text { calibration }\end{array}$ & \multicolumn{2}{|c|}{ Data used for model building } \\
\hline \multirow{5}{*}{ Stresses } & Vertical stress Sv & Density $\log$ & Type of rock & Assumption $\approx 1 \mathrm{psi} / \mathrm{ft}$ \\
\hline & Pore pressure Po & $\begin{array}{l}\text { Formation test, DST, } \\
\text { Drilling data }\end{array}$ & Resistivity log or Sonic log & $\begin{array}{l}\text { Assumption } \approx 0.44 \\
\text { psi/ft }\end{array}$ \\
\hline & \begin{tabular}{|l|} 
Minimum \\
principal \\
horizontal stress \\
Shmin \\
\end{tabular} & $\begin{array}{l}\text { Leak Off Test (LOT), or } \\
\text { Minifracture Test, or } \\
\text { Extended LOT, FMI }\end{array}$ & Correlation from Sv and Po & $\begin{array}{l}\text { Type of fault \& } \\
\text { Anderson graph }\end{array}$ \\
\hline & \begin{tabular}{|l|} 
Maximum \\
principal \\
horizontal stress \\
Shmax \\
\end{tabular} & $\begin{array}{l}\text { Leak Off Test (LOT), or } \\
\text { Minifracture Test, or } \\
\text { Extended LOT, FMI }\end{array}$ & $\begin{array}{l}\text { Caliper log and/or Correlation } \\
\text { from Shmin \& Po }\end{array}$ & $\begin{array}{l}\text { Type of fault \& } \\
\text { Anderson graph }\end{array}$ \\
\hline & $\begin{array}{l}\text { Concentration } \\
\text { stress around } \\
\text { wellbore }\end{array}$ & $\begin{array}{l}\text { SHmax, Shmin, Po, } \\
\text { well trajectory }\end{array}$ & $\begin{array}{l}\text { SHmax, Shmin, Po, well } \\
\text { trajectory }\end{array}$ & \\
\hline \multirow{2}{*}{$\begin{array}{c}\text { Rock } \\
\text { mechanical } \\
\text { properties }\end{array}$} & $\begin{array}{l}\text { Young modulus } \\
\text { \& Poisson ratio }\end{array}$ & Tri-axial test & $\begin{array}{l}\text { Compressional \& Shear sonic } \\
\text { logs }\end{array}$ & Type of rock \\
\hline & $\begin{array}{l}\text { Unconfined } \\
\text { Compressive } \\
\text { Strength UCS }\end{array}$ & Core UCS test & $\begin{array}{l}\text { Empirical correlationsform: } \\
\text { porosity, and/or Vclay, and/or } \\
\text { compressional wave velocity }\end{array}$ & Type of rock \\
\hline
\end{tabular}

Let us take the Fracture toughness for example. The most accurate information should be the core test data. However, the core collection as well as the test cost considerably high and pose difficulties in operation. Hence in many case we do not have the core test data for fracture toughness. In this case, if we have Young modulus of the rock or sonic logs, empirical correlations can be used to determine fracture toughness $\left(\mathrm{K}_{\mathrm{IC}}-\mathrm{MPa}^{-1 / 2}\right)$ according to Whittaker et al. [8]:

$\mathrm{K}_{\mathrm{IC}}=0.336+0.026 . \mathrm{E}$

[Equation 1]

or according to Chenzixi et al. [9] for sandstone:

$$
\begin{array}{ll}
\mathrm{K}_{\mathrm{IC}}=-0.332+0.000361 . \mathrm{Vp} & {[\text { Equation 2] }} \\
\mathrm{K}_{\mathrm{IC}}=0.0006147 . \mathrm{Vs}-0.5517 & {[\text { Equation 3] }} \\
\mathrm{K}_{\mathrm{IC}}=0.0215 . \mathrm{E}+0.2468 & {[\text { Equation 4] }}
\end{array}
$$

where E: Young modulus (GPa)

$\mathrm{Vp}$ : velocity of compressive wave $(\mathrm{m} / \mathrm{s})$

Vs: velocity of shear wave $(\mathrm{m} / \mathrm{s})$

And in case we do not have any of above information, the fracture toughness can still be deduced from type of rock if we have this kind of information. Certainly the value determined in this way will be the least accurate. Hence, in order to have an accurate geomechanical model, it is always better to have in-situ updated information, such as core test, formation test and $\operatorname{logs}$ data.

\section{CASE STUDY: GEOMECHANICAL MODELLING FOR THE WELL $X$}

\subsection{Data acquisition}

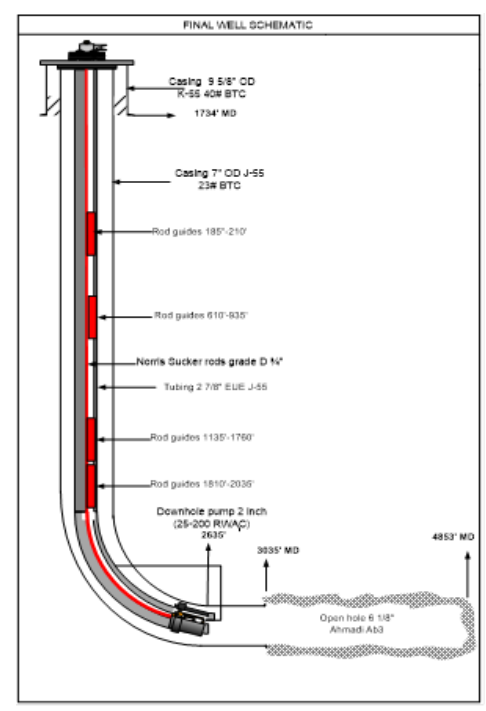

Figure 2. Schematic of the well $X$ 
Table 2. Available data useful for geomechanical modeling of the well $\mathrm{X}$.

\begin{tabular}{|l|l|}
\hline $\begin{array}{l}\text { Type of } \\
\text { information }\end{array}$ & Available data \\
\hline Well data & $\begin{array}{l}\text { Wellbore diameter (6.125 in } \\
\text { open hole), Completion depth } \\
\text { (TVD 2417 ft) }\end{array}$ \\
\hline Logs \& Test Data & Resistivity log \\
\hline $\begin{array}{l}\text { Geological } \\
\text { information }\end{array}$ & $\begin{array}{l}\text { Type of fault (Normal), Type } \\
\text { of rock (limestone) }\end{array}$ \\
\hline
\end{tabular}

The well $\mathrm{X}$ schematic is presented in Figure 2 which shows that the horizontal length is about $1818 \mathrm{ft}$. The data acquisition is summarized in Table 2 . It is worthy noted that the Table 2 summarized only the available information that was useful for geomechanical modeling.

\subsection{Data analysis \& Geomechanical parameter determination}

We can remark that some critical test data are missing, such as the test for pore pressure (XPT), for minimum \& maximum horizontal stresses (LOT, XLOT, Minifrac, Caliper), and for rock mechanical properties (Core tests). Moreover, the density $\log$ is missing so the determination of vertical stress will be less accurate.

One more important remark is that the well is horizontal, so the stress must be calculated using TVD. Unfortunately the MD versus TVD is not available, so we had to use these following assumptions:

- The well is perfectly vertical until MD $2036 \mathrm{ft}$ (Figure 2)

- From MD $2036 \mathrm{ft}$ to MD $2635 \mathrm{ft}$, the well is curved in circle with an arc length of 2635$2036=599 \mathrm{ft}$, the angle is $90^{\circ}$, so the radius is $599 \mathrm{ft} /(\pi / 2)=381 \mathrm{ft}$

- From MD $2635 \mathrm{ft}$ to $4853 \mathrm{ft}$ the well is perfectly horizontal
The vertical stress $\sigma_{\mathrm{v}}$ was calculated from assumption on type of rock (limestone). The density of limestone in this region was about 2.5 g/cc.

The pore pressure $\left(\mathrm{P}_{\mathrm{o}}\right)$ was calculated using resistivity log basing on Eaton's method:

$\mathrm{P}_{0}=\sigma_{\mathrm{v}}-\left(\sigma_{\mathrm{v}}-\mathrm{P}_{\mathrm{hyd}}\right) *\left[\frac{\mathrm{R}_{\mathrm{log}}}{\mathrm{R}_{\mathrm{n}}}\right]^{1.2} \quad$ [Equation 5]

The hydrostatic pressure $\mathrm{P}_{\text {hydrostatic }}$ was about $0.46 \mathrm{psi} / \mathrm{ft}$.

The subscripts $n$ and $\log$ refer to the normal and measured values of resistivity $(R)$. The exponents shown in the Equation 5 are typical values that are often changed for different regions so that the predictions better match pore pressures inferred from other data. In our case we do not have other data so we assumed the exponent factor to be 1.2 as given by Eaton method. The normal values of $\mathrm{R}$ is determined using trend-line method. However, the major problem with all trend-line methods is that the user must pick the correct normal compaction trend. Sometimes there are too few data to define the Normal Compaction Trendline (NCT), sometimes the data are too noisy to draw a correct NCT, which is our case. Hence, in order to determine NCT, one of the possibilities is to use the Equation 6 given by Zhang [10]:

$$
\mathrm{R}_{\mathrm{n}}=\mathrm{R}_{0} \mathrm{e}^{\mathrm{bZ}} \quad \text { [Equation 6] }
$$

where $\mathrm{R}_{0}$ is the resistivity in the mudline; $b$ is the slope of logarithmic resistivity normal compaction trendline; $\mathrm{Z}$ is the TVD below the mudline. We do not have Formation test data so we could not calibrate the pore pressure model, hence we assumed b to be equal to 0.000034 [10]. It should be noted that the pore pressure in the formation near the wellbore is affected by drilling induced stresses. Therefore, in order to obtain the formation pore pressure the deep 
resistivity is needed for the pore pressure calculation. In our case, the resistivity $\log$ is available but we do not have the $\mathrm{R}_{0}$ (resistivity in the mudline). Hence, we make assumption that the pore pressure is equal to the hydrostatic pressure (assumed to be about $0.46 \mathrm{psi} / \mathrm{ft}$ ).

The minimum horizontal stress was calculated according to Equation 7 [4]:

$\sigma_{\mathrm{h}}=\left(\frac{\mathrm{v}}{1-\mathrm{v}}\right)\left(\sigma_{\mathrm{v}}-\alpha \mathrm{P}_{0}\right)+\alpha \mathrm{P}_{\mathrm{o}}+\sigma^{\mathrm{T}} \quad$ [Equation 7]

where $\sigma^{\mathrm{T}}$ is tectonic stress which was taken to be 0 ; $\mathrm{v}$ is Poisson ratio which was taken to be 0.3 for limestone. The Equation 7 is applied only to Normal fault, which is our case. For other types of fault, we can find suitable empirical equations in [4].

The maximum horizontal stress might be calculated from Shmin, pore pressure, combined with Drilling-Induced Tensile Fracture or with Wellbore failure analysis (Breakout), but this is not possible in our case due to lack of data. In this case, we determined the maximum horizontal stress using Anderson's theory: At each depth, the range of possible values of Shmin and SHmax are established by (i) Anderson faulting theory (which defines the relative stress magnitude), (ii) the fact that the least principal stress must always exceed the pore pressure (to avoid hydraulic fracturing) and (iii) the difference between the minimum and maximum principal stress which cannot exceed the strength of the crust (which depends on depth and pore pressure). An example of Anderson's graph for normal fault is given in Figure 3.

Due to lack of core test data, the fracture toughness mode I was taken to be $0.99 \mathrm{MPa}^{-}$ ${ }^{1 / 2}\left(900\right.$ psi.in $\left.^{-1 / 2}\right)$. This value was the test result for limestone taken from paper of Schimdt [11].
The tensile strength was calculated from Fracture Toughness mode I using empirical correlation of Whittaker et al. [7]:

$$
\mathrm{T}=9.35 \mathrm{~K}_{\mathrm{IC}}-2.53 \quad \text { [Equation 8] }
$$

With $\mathrm{T}$ in MPa and $\mathrm{K}_{\mathrm{IC}}$ in MPa.m $\mathrm{m}^{-1 / 2}$

Young modulus \& Poisson ratio were calculated from Fracture Toughness mode I using empirical correlation of Whittaker et al. [7]: $\mathrm{K}_{\mathrm{IC}}=0.336+0.026 . \mathrm{E}$ with $\mathrm{E}$ is $\mathrm{GPa}$ and $\mathrm{K}_{\mathrm{IC}}$ is MPa. $\mathrm{m}^{-1 / 2}$.

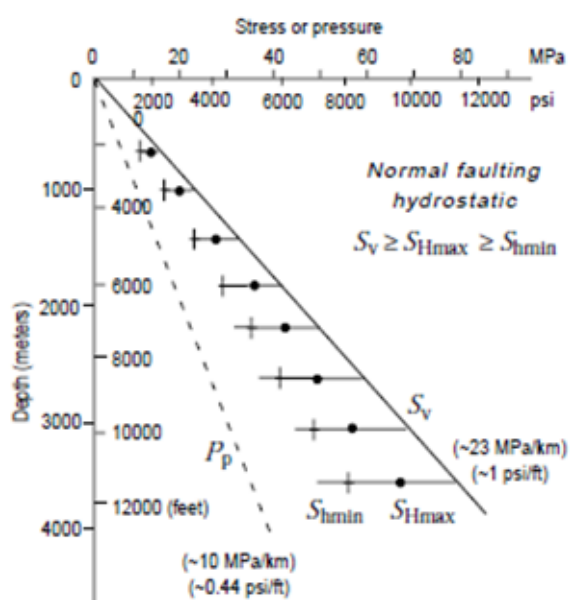

Figure 3. Variation of stress magnitudes with depth in normal faulting stress regimes for hydrostatic conditions [4]

We now calculate the minimum horizontal pressure Shmin using Equation 7 of Zoback [4] in which $\sigma^{\mathrm{T}}$ (tectonic stress) was assumed to be 0 and $\mathrm{v}$ (Poisson ratio) was assumed to be 0.3 for limestone. For cross check, the Shmin is also determined from Anderson's graph for normal fault (Figure 3). The minimum horizontal stress is determined to be about $1672 \mathrm{psi}$ at $2417 \mathrm{ft}$ TVD (this is the depth where mechanical well simulation is intended to be done). In the same manner, the maximum horizontal stress is determined to be about $2000 \mathrm{psi}$ at $2417 \mathrm{ft}$ TVD. At this depth, the fracture toughness mode I for limestone was taken to be $0.99 \mathrm{MPa}^{-1 / 2}(900$ 
psi.in $^{-1 / 2}$ ) [11]. Hence, the tensile strength is about $7.78 \mathrm{MPa}$.

The concentration stress around the wellbore is calculated for a horizontal well. We need to do an axis transformation. Then, the tangential stress at the borehole wall varies between the maximum value $\sigma \theta, \max =3 \sigma \mathrm{H}-$ $\sigma \mathrm{h}-p \mathrm{w}$ and the minimum value $\sigma \theta, \min =3 \sigma \mathrm{h}$ $-\sigma \mathrm{H}-p \mathrm{w}$ [3]. We remark that the maximum and minimum values of concentration stress for deviated wellbore are different from the values for a vertical wellbore [4], which are : the maximum value $\sigma \theta, \max =3 \sigma \mathrm{H}-\sigma \mathrm{h}-2 . p \mathrm{w}$ and the minimum value $\sigma \theta, \mathrm{min}=3 \sigma \mathrm{h}-\sigma \mathrm{H}-2 . p \mathrm{w}$. This is a very important point to be taken into account for deviated and horizontal wells. These equations show that for the same values of pore pressure and maximum and minimum principal horizontal stresses, a horizontal well sustains higher concentration stress than vertical well. Another difference between deviated and vertical wells is the direction for perforation and/or for mechanical well stimulation (fracturing). For vertical well, it is well known that the perforation direction should be the one of maximum principal horizontal stress. However, it is not the same for horizontal well where the perforation direction should be determined in function of the type of fault and of the direction of the well. The same remark was mentioned in the literature for the geometry development of fractures induced by hydraulic fracturing. These discussion points are out of scope in this paper so we mention here only the remarks.

\section{APPLICATION OF GEOMECHANICAL MODEL FOR PREDICTION OF HIGH ENERGY GAS FRACTURING PERFORMANCE}

The geomechanical model built was then used to predict the High Energy Gas Fracturing performance for the well $\mathrm{X}$. The HEGF is a well-stimulation method based on solidpropellant, capable of generating multiple fractures in the reservoir rock when the proper energy-time profile is applied to the wellbore. Such multiple fractures networks have a high probability of intersecting natural fractures and therefore increase the permeability of the near wellbore region. However, the HEGF job cost considerably high and therefore its performance must be evaluated before realizing.

For a rectilinear fracture, the minimum pressure required to extend the fracture is:

$$
\mathrm{P}_{m}=\sigma+\frac{K_{I C}}{\sqrt{\pi X_{L}}} \text { [12] [Equation 9] }
$$

With $\mathrm{K}_{\mathrm{IC}}$ is fracture toughness, $\sigma$ is the minimum value of concentration stress around wellbore and $\mathrm{X}_{\mathrm{L}}$ is the fracture length.

According to Stoller [12], the fracture volume and fracture width are:

$$
\begin{array}{ll}
V=\frac{16 . K_{n}\left(1-v^{2}\right)(P-\sigma) X_{L}^{2} H}{E} & \text { [Equation 10] } \\
w_{w b}=\frac{8 . M_{n}\left(1-v^{2}\right)(P-\sigma) X_{L}}{E} & \text { [Equation 11] }
\end{array}
$$

With $\mathrm{v}$ is Poisson ratio, $\mathrm{E}$ is Young modulus, $\mathrm{Kn}$ and $\mathrm{Mn}$ are empirical constants depending on the number of fractures, $\mathrm{H}$ is fracture height (assumed to be the reservoir thickness).

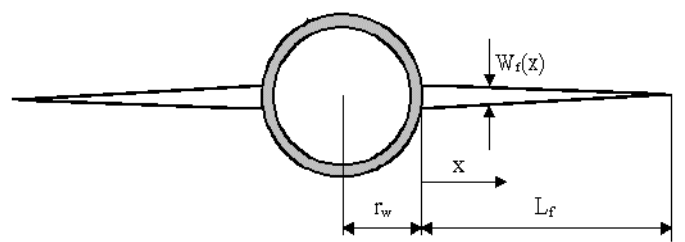

Figure 4. Fracture geometry.

We can see clearly that the geomechanical modeling is heavily involved in these steps. The 
accuracy of the HEGF performance prediction depends therefore closely on the accuracy of the geomechanical model.

From the geomechanical model determined for the well $\mathrm{X}$ in the previous section, we determined the fracture length after a HEGF job. The result of fracture length presented in Table 3 showed good accordance with litterature results [13].

Table 3. Prediction results of High Energy Gas Fracturing performance

\begin{tabular}{|l|l|l|l|l|l|l|l|l|}
\hline $\begin{array}{l}\text { Pore } \\
\text { pressure } \\
\text { (psi) }\end{array}$ & $\begin{array}{l}\text { Shmin } \\
\text { (psi) }\end{array}$ & $\begin{array}{l}\text { SHmax } \\
\text { (psi) }\end{array}$ & $\begin{array}{l}\text { E } \\
\text { (Mpa) }\end{array}$ & $\begin{array}{l}\text { K IC } \\
(\mathbf{M p a} \\
\mathbf{1} / \mathbf{2})\end{array}$ & $\begin{array}{l}\text { T } \\
\text { (Mpa) }\end{array}$ & k (mD) & $\begin{array}{l}\text { Reservoir } \\
\text { radius (ft) }\end{array}$ & $\begin{array}{l}\text { Fracture } \\
\text { Length } \\
(\mathbf{m})\end{array}$ \\
\hline 1111 & 1672 & 2000 & 25154 & 0.99 & 6.73 & 1 & 622 & $\mathbf{4 . 6 9}$ \\
\hline
\end{tabular}

\section{APPLICATION OF GEOMECHANICAL MODEL FOR SAND CONTROL}

Another application of this geomechanical model is to study the Sand Control. The sand production in reservoirs is mainly driven by: 1) Depletion-induced stress path causing changes mainly in horizontal stresses; 2) Failure of mainly sandstones apart from interbedded nondepleting shales; 3) Perforation failure; and 4) Shear failure due to high flowrate.

Sand production can causes serious problems to the production (e.g. erosion of downhole and surface equipment, accumulation of sand in downhole and surface equipment, formation collapse), hence the best safeguard is to integrate the sand production risk assessment in the field development planning study, so different sand control scenarios can be prepared.

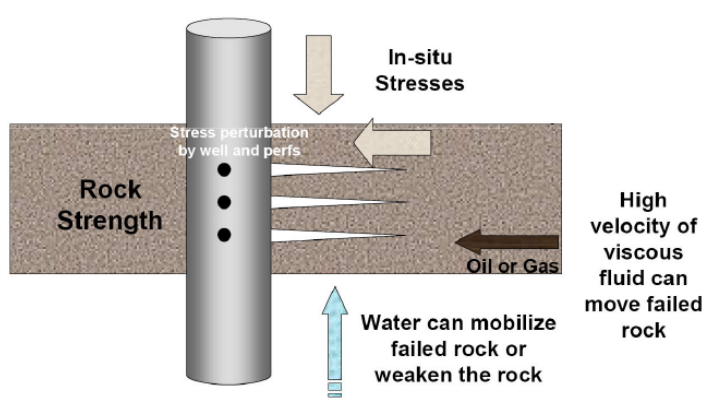

Figure 5. Rock failure occurs when stress exceeds strength
Condition for no sand production:

$$
\mathrm{S}_{\mathrm{t} 2}-\mathrm{P}_{\mathrm{wf}}<\mathrm{U}
$$

[Equation 12]

$\mathrm{S}_{\mathrm{t} 2}$ : maximum concentration stress at bore hole

$\mathrm{P}_{\mathrm{wf}}$ : Bottomhole pressure

$\mathrm{U}$ : Effective strength of the formation, estimated equal to TWC (Thick-Wall Cylinder) (safest case), or equal to TWC multiplied by an empirical constant.

The TWC can be related to UCS by empirical correlations. For example: for moderate to very strong sandstones:

$$
\mathrm{TWC}=80.8765 \times \mathrm{UCS}^{0.58} \quad \text { [Equation 13] }
$$

and for very unconsolidated sandstones:

$$
\mathrm{TWC}=37.5 \times \mathrm{UCS}^{0.6346} \quad \text { [Equation 14] }
$$

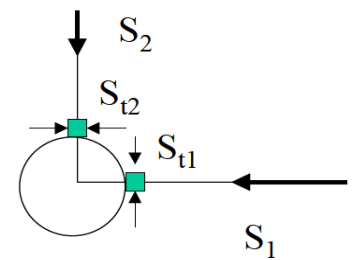

Figure 6. Tangential stress (concentration stress) at the wall of a hole.

$\mathrm{S}_{\mathrm{t} 1}=3 \mathrm{~S}_{2}-\mathrm{S}_{1}-\mathrm{P}_{\mathrm{wf}}(1-\mathrm{A})-$ A.P $\quad$ [Equation 15]

$\mathrm{S}_{\mathrm{t} 2}=3 \mathrm{~S}_{1}-\mathrm{S}_{2}-\mathrm{P}_{\mathrm{wf}}(1-\mathrm{A})-$ A.P $\quad$ [Equation 16]

$A=\frac{(1-2 v) \alpha}{1-v} \quad$ [Equation 17] 
$\mathrm{S}_{1}$ : Maximum horizontal stress on the wellbore plan

$\mathrm{S}_{2}$ : Minimum horizontal stress on the wellbore plan

$\mathrm{P}_{\mathrm{o}}$ : Pore pressure (this is the reservoir pressure at the near wellbore region)

v: Poisson ratio

$\alpha$ : Biot constant, assumed to be around 1

From Equation 12 and Equation 16, we have :

$P_{w f}>\frac{1}{2-A} \cdot\left[-A \cdot P_{0}+\left(3 \cdot S_{1}-S_{2}-U\right)\right]^{[\text {Equation 18] }}$

We can calculate the Critical Drawdown Pressure as following:

$C D P=P_{0}-P_{w f}=\frac{1}{2-A} \cdot\left[2 \cdot P_{0}-\left(3 \cdot S_{1}-S_{2}-U\right)\right]$

[Equation 19]

CDP is the maximum drawdown to be in the free sand production. If the drawdown is higher than CDP, sand will be produced.

And the Critical Bottomhole Flowing Pressure is:

$$
\mathrm{CBHFP}=\mathrm{Po}-\mathrm{CDP} \quad[\text { Equation 20] }
$$

For the case study, we analyse the sand production prediction for a well $\mathrm{Y}$ with below geomechanical parameters (Table 4).

Table 4. Geomechanical model of the well Y

\begin{tabular}{|l|c|}
\hline $\begin{array}{l}\text { Geomechanical } \\
\text { Properties }\end{array}$ & $\begin{array}{c}\text { Values Calculated at } \\
\text { Perforation Depth (12500 ft) }\end{array}$ \\
\hline Pore pressure & $8000 \mathrm{psi}$ \\
\hline Vertical stress & $12861 \mathrm{psi}$ \\
\hline Shmin & $9805 \mathrm{psi}$ \\
\hline Shmax & $11333 \mathrm{psi}$ \\
\hline Tensile Strength & $7.78 \mathrm{Mpa}$ \\
\hline Poisson Ratio & 0.3 \\
\hline UCS & $8000-10000 \mathrm{psi}$ \\
\hline
\end{tabular}

\section{Trang 12}

\begin{tabular}{|l|c|}
\hline Type of fault & Normal \\
\hline Deviation & Horizontal well \\
\hline $\begin{array}{l}\text { Type of reservoir } \\
\text { rock }\end{array}$ & Limestone \\
\hline Rerservoir thickness & $8 \mathrm{ft}$ \\
\hline Reservoir radius & $622 \mathrm{ft}$ \\
\hline Skin & -3.69 \\
\hline Permeability & $1 \mathrm{mD}$ \\
\hline
\end{tabular}

For equations $13 \& 14$ to estimate the TWC, the UCS must be known. Normally, the UCS can be determined from sonic log according to the following equation:

$$
\mathrm{UCS}=838825 * \mathrm{e}^{-0.057 \mathrm{Dt}}[14] \quad \text { [Equation 21] }
$$

With Dt is the Compressional Wave Transit Time $(\mu \mathrm{s} / \mathrm{ft})$.

However in reality many times the sonic $\log$ is not available. For the well Y, we estimate the value of UCS for limestone to be ranged from 8000 to 10000 psi. The UCS sensitivity analysis is presented in Figure 7. We remark that:

- Sand-free drawdown at initial reservoir pressure 8000 psi

- Can be produced sand-free with a constant drawdown of 5000 psi until the reservoir depletes to $6000 \mathrm{psi}$

- For reservoir pressure under 6000 psi, we can still have sand-free production but the drawdown must be adjusted

- No sand-free production for reservoir pressure under 2300 psi which should lead to well abandonment 


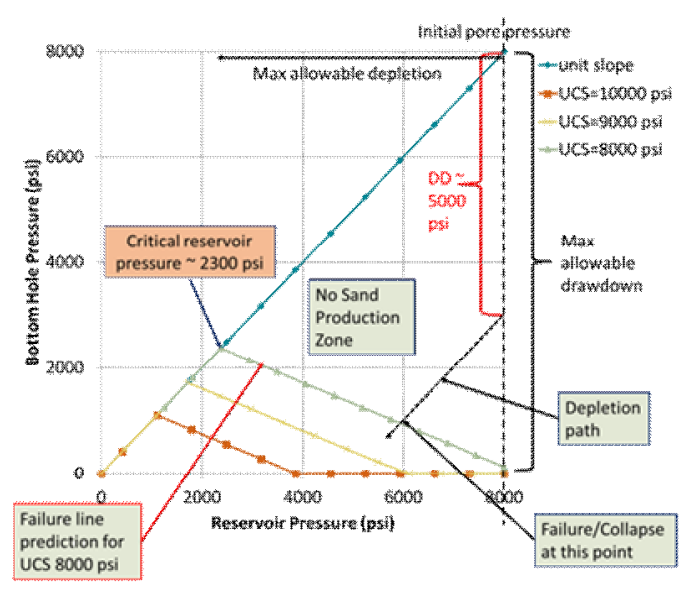

Figure 7. Sand Production Assessment - UCS sensitivity study.

The well trajectory sensitivity analysis is presented in Figure 8. We remark that sand-free production zone becomes smaller when the well becomes more deviated.

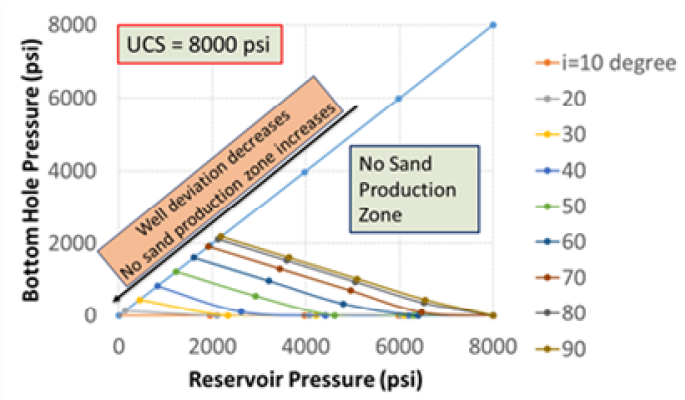

Figure 8. Sand Production Assessment - Well deviation sensitivity study.

\section{CONCLUSIONS}

This paper presented: 1) General workflow for building a geomechanical model; 2) Detailed data acquisition with different kinds of data; 3 ) Detailed data analysis with different ways to determine geomechanical parameters so that in case of data missing the geomechanical model can still be built. Hence, the number of assumptions and uncertainties can be reduced; 4) Application of geomechanical modeling in HEGF study and Sand Control analysis.

The accuracy of results of HEGF study and Sand Control analysis depend considerably on the accuracy of the Geomechanical model. Evidently, if we have more available data \& tests, we will have less assumptions \& uncertainties and the geomechanical model will be more accurate. However, when we encounter data missing problems, we can still do geomechanical modeling, with help of different ways to determine geomechanical parameters. 


\section{Mô hình địa cơ học - Quy trình xây dựng và các áp dụng}

- Phạm Sơn Tùng

- Mai Cao Lân

Bộ môn Khoan \& Khai thác Dầu khi, Khoa Kỹ thuật Địa chất \& Dầu khí, Trường Đại học Bách khoa, ĐHQG-HCM

\section{TÓM TĂT}

Bài báo này giới thiệu quy trình xây dưng mô hìn địa co học. Bước đầu tiên để xây dưng mô hình địa co học là tập hợp số liệu liên quan đến giếng (ống khai thác, ống chống, độ nghiêng...), thông tin địa chất (loại đưt gãy, độ thấm, bán kính via, hệ số skin...), số liệu đo log (điện trở suất, siêu âm...), thí nghiệm hiện truờng (thí nghiệm leak-off, thí nghiệm áp suất lỗ rỗng...) và thí nghiệm mẫu (thí nghiệm kéo, độ kháng nưt, nén ba trục...). Bước tiếp theo để xây dựng mô hình địa cơ học là xác định các thông số liên quan đến trạng thái ứng suất (ứng suất thẳng đứng, ưng suất chính lớn nhất và nhỏ nhất, áp suất lỗ rỗng, ưng suất tập trung quanh lỗ giếng) và các tính chất co học của đất đá (khả năng chịu nén nở hông, độ bền kéo, độ kháng nưt, module Young và hệ số Poisson). Ngoài ra nhũng điểm khác nhau trong quá trình phân tích số liệu đối với giếng đứng và giếng nghiêng cũng được đề cập đến. Một điều hiển nhiên là nếu chúng ta có càng nhiều số liệu thì mô hình địa co học sẽ được xây dưng càng chính xác. Tuy nhiên trong thực tế sẽ gặp nhũng truòng hợp bị thiếu số liệu. Bài báo này vì vậy cung đề cập tới chúng ta phải làm gì để có thể thu được tối đa các thông tin cần thiết tù̀ nhũng số liệu có sã̃n, dù it dù nhiều, nhằm hạn chế tối đa việc phải sủ dụng các giả thiết gây ảnh huơong tới mức độ chính xác của mô hình địa co học. Việc xây dựng mô hình địa co học sát với thưc tế nhất là rất quan trọng vì mô hình này sẽ được ưng dụng trong các công việc khác nhu tính toán ổn định giếng khoan, dụ đoán hiệu quả của các phroong pháp kich thich via, kiểm soát sinh cát. Sau khi giói thiệu quy trình xây dụng mô học địa co họ, bài báo sẽ lấy ví du cu thể tính toán cho giếng $X$ và sử dụng mô hình đó để dụ báo kết quả của quá trình nứt via bằng phưong pháp khí áp cao. Một ví du áp dung khác mà bài báo cũng sẽ đề cập tới là kiểm soát sinh cát.

Tù khóa: Mô hình địa co học, Nứt vỉa bằng phuong pháp khí áp cao, Kiểm soát sinh cát.

\section{REFERENCES}

[1]. Zoback M.L., "First and second order patterns of stress in the lithosphere, the World Stress Map Project", J. Geophys. Res., 97, 703-728, 1992.
[2]. Spener B., Mueller B., Heidbach O., Delvaux D., Reinecker J., Fuchs K., "Tectonic stress in the Earth's crust, advances in the World Stress Map project", Geol. Soc. Spec. Publ., 212, 101-116, 2003. 
[3]. Fjaer, E., Holt, R. M., Horsrud, P., Raaen, A. M., and Risnes, R., "Petroleum Related Rock Mechanics, 2nd edn.", Developments in Petroleum Science, Elsevier, Maryland Heights, 2008.

[4]. Zoback M.L., "Reservoir Geomechanics", Cambridge University Press, Cambridge, 2007.

[5]. Maerten L., Gillespie P., Pollard D.D., "Effects of local stress perturbation on secondary fault development", J. Struct. Geol., 24, 145-153, 2002.

[6]. Yale D.P., "Fault and stress magnitude controls variations in the orientation of in situ stress, in: Fracture and In-Situ Stress Characterization of Hydrocarbon Reservoir", edited by: Ameen M., Special Publications, Geological Society, London, 55-64, 2003.

[7]. Fischer K., "Geomechanical reservoir modeling - workflow and case study from the North Basin German”, Ph.D. Thesis, Technical University of Darmstadt, 2013.

[8]. Whittaker B.N., Singh R.N., Sun G., "Rock fracture Mechanics", Elsevier Science, London, U.K, 1992.

[9]. Chenzixi, "Determination of Rock Fracture Toughness and Its Relationship with Acoustic Velocity", Int. J. Rock Mech. \& Min. Sci. Vol. 34, No.3-4, Elsevier, 1997.
[10].Jincai Zhang, "Pore pressure prediction from well logs: Methods, modifications, and new approaches", Earth-Science Reviews, Volume 108, Issues 1-2, pp. 5063, 2011.

[11].Richard A. Schmidt, "Fracture Toughness Testing of Limestone", Experimental Mechanics, Vol 16, Issue 5, pp. 161-167, 1976.

[12].H.M.Stoller, "A perspective on tailored pulse loading: a new approach to oil and gas well stimulation", SPE 13860, Low permeability gas reservoirs conference, Denver, Colorado, May 19-22, 1985.

[13].Richard A. Schmidt, Norman R. Warpinski, Paul W. Cooper, "In-situ evaluation of several tailored-pulse well-shooting concepts", SPE 8934, SPE Symposium on Unconventional Gas Recovery, Pennsylvania, May 18-21, 1980.

[14].A. Khaksar, P.G. Taylor, Z. Fang, T.J.Kayes, A.Salazar, K.Rahman, "Rock Strength from Core and Logs: Where We Stand and Ways to Go", SPE-121972-MS, EUROPEC/EAGE Conference and Exhibition, Amsterdam, The Netherlands, 2009. 